\title{
Political Theory Today: Results of a National Survey
}

Matthew J. Moore, California Polytechnic State University

\section{ABSTRACT This article reports the results of a 2008 national survey of political theo-} rists. The results, based on 1,086 responses from professors at accredited, four-year colleges and universities in the United States, provide information about the demographic characteristics of political theorists, opinion data on the place of political theory within political science, the proportion of political theorists in political science departments, teaching loads, expectations for tenure, the experience of political theorists on the academic job market, and, finally, rankings of theorists, journals, publishers, professional organizations, and Ph.D. programs.

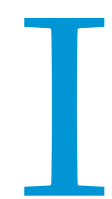
$\mathrm{n}$ the fall of 2008, I conducted a survey of political theorists in the United States. ${ }^{1}$ The survey asked a wide range of questions about the place of political theory within political science, the experiences of political theorists as teachers and scholars, and about what and how political theorists teach. ${ }^{2}$ My goal was to investigate theorists' views on the long-running debate over whether political theory belongs in political science, ${ }^{3}$ as well as to get a snapshot view of the practice of political theory as a subfield today. For purposes of the survey, I defined political theory as the study of political philosophy, including both normative and historical approaches, but not including positive political theory or formal modeling.

My research assistants ${ }^{4}$ and I visited the webpage of every accredited, four-year college and university in the United States to attempt to identify potential participants. We also included everyone in the American Political Science Association's (APSA) Directory of Political Science Faculty and Programs, 20072008 (2007) who listed an interest in political theory (not including positive political theory). We included everyone who could not be excluded.

Of the 2,073 schools we identified, $59.1 \%(1,226)$ include political theory in their curriculums, while $20.3 \%$ (420) include political science but not political theory, and $14.8 \%$ (306) do not teach political science at all (in any department). We attempted to verify these findings by examining school catalogs. Through this process, we identified 5,144 potential respondents-roughly half people whom we had reason to believe were political theorists, and roughly half people we could not rule out. After deducting bounced emails, undeliverable letters, and respondents who identified themselves as ineligible, 4,351 potential respondents received an invitation to take the online survey. By the time data collection had closed, 1,086 individuals had completed some or all of the survey, pro- ducing a simple response rate (total responses/total invitations received by potential respondents) of $25 \%(1,086 / 4,351)$. The response rate among scholars we now had reason to believe are political theorists and who received the invitation 5 was $49 \cdot 3 \%(1,086 / 2,203)$.

One simple, initial question of interest is: who are political theorists? Many of the answers to this question are not surprising, such as that $96.1 \%(745 ; N=775)$ of respondents hold a Ph.D. or equivalent, or that $81 \%(628 ; N=775)$ of respondents teach in a political science department. (Since not every respondent answered every question, I will indicate the $N$ for each topic.) However, one finding of note concerns gender. According to the APSA (2001), 23.8\% of political scientists are women, whereas $26.6 \%(205 ; N=771)$ of survey respondents were women, suggesting that political theory has a slightly higher proportion of women than does the profession generally. (As of February 2010, $31.8 \%$ of the APSA's members are women, but, as I report below, not all political scientists are members of the APSA, so that figure may not be representative of the broader population.) Similarly, while it should be no surprise, only $25 \cdot 3 \%$ (270) of respondents were at institutions that grant a Ph.D. in political science, while $74.7 \%(798 ; N=1,068)$ were not.

One final demographic question concerns how the respondents, all of whom reported teaching at least some political theory, relate to political theory itself. I have broken the respondents into three categories: (1) Theorists by Necessity, whose primary research or teaching interests are not in political theory (27.3\% [211] of respondents); (2) Theorists at Heart, whose primary teaching or research interests are in political theory and who teach at least $25 \%$ of the time in political theory $(58.9 \%$ [456] of respondents); and (3) Would-Be Theorists, whose primary teaching or researching interests are in political theory but who teach theory less than $25 \%$ of the time $(13.8 \%$ [107; $N=$ 774] of respondents). 
Table 1

Respondents' Views on the Place of Political Theory within Political Science

\begin{tabular}{|c|c|c|c|c|c|c|}
\hline & $\begin{array}{l}\text { STRONGLY } \\
\text { AGREE }\end{array}$ & AGREE & NOT SURE & DISAGREE & $\begin{array}{l}\text { STRONGLY } \\
\text { DISAGREE }\end{array}$ & $\begin{array}{l}\text { ROW } \\
\text { TOTALS }\end{array}$ \\
\hline Political theory is an essential part of political science. & $\begin{array}{l}85.0 \% \\
(668)\end{array}$ & $\begin{array}{c}12.3 \% \\
(97)\end{array}$ & $\begin{array}{l}1.4 \% \\
(11)\end{array}$ & $\begin{array}{l}1.0 \% \\
(8)\end{array}$ & $\begin{array}{l}0.3 \% \\
(2)\end{array}$ & $\begin{array}{l}100 \% \\
(786)\end{array}$ \\
\hline $\begin{array}{l}\text { Political theory articles are given a fair chance at publication } \\
\text { in major political science journals. }\end{array}$ & $\begin{array}{l}4.1 \% \\
(32)\end{array}$ & $\begin{array}{c}19.5 \% \\
(152)\end{array}$ & $\begin{array}{l}37.7 \% \\
(294)\end{array}$ & $\begin{array}{l}32.2 \% \\
(251)\end{array}$ & $\begin{array}{l}6.5 \% \\
(51)\end{array}$ & $\begin{array}{l}100 \% \\
(780)\end{array}$ \\
\hline $\begin{array}{l}\text { The number of political theory articles published in major } \\
\text { political science journals properly reflects the importance } \\
\text { of political theory to the discipline of political science. }\end{array}$ & $\begin{array}{l}3.3 \% \\
(26)\end{array}$ & $\begin{array}{c}11.2 \% \\
(87)\end{array}$ & $\begin{array}{c}25.9 \% \\
(202)\end{array}$ & $\begin{array}{l}44.9 \% \\
(350)\end{array}$ & $\begin{array}{c}14.7 \% \\
(114)\end{array}$ & $\begin{array}{l}100 \% \\
(779)\end{array}$ \\
\hline $\begin{array}{l}\text { Political theory books are given a fair chance at publication } \\
\text { by major university presses. }\end{array}$ & $\begin{array}{l}6.4 \% \\
(50)\end{array}$ & $\begin{array}{c}34.6 \% \\
(269)\end{array}$ & $\begin{array}{c}40.0 \% \\
(311)\end{array}$ & $\begin{array}{c}16.3 \% \\
(127)\end{array}$ & $\begin{array}{l}2.7 \% \\
(21)\end{array}$ & $\begin{array}{l}100 \% \\
(778)\end{array}$ \\
\hline $\begin{array}{l}\text { Political theory paper and panel proposals are given a fair chance } \\
\text { of being selected at major political science conferences. }\end{array}$ & $\begin{array}{l}8.0 \% \\
(62)\end{array}$ & $\begin{array}{c}44.4 \% \\
(345)\end{array}$ & $\begin{array}{c}30.6 \% \\
(238)\end{array}$ & $\begin{array}{c}14.2 \% \\
(110)\end{array}$ & $\begin{array}{l}2.8 \% \\
(22)\end{array}$ & $\begin{array}{c}100 \% \\
(777)\end{array}$ \\
\hline $\begin{array}{l}\text { The number of political theory panels at major political science } \\
\text { conferences properly reflects the importance of political theory } \\
\text { to the discipline of political science. }\end{array}$ & $\begin{array}{l}4.8 \% \\
(37)\end{array}$ & $\begin{array}{l}31.1 \% \\
(241)\end{array}$ & $\begin{array}{l}34.1 \% \\
(264)\end{array}$ & $\begin{array}{c}25.5 \% \\
(197)\end{array}$ & $\begin{array}{l}4.5 \% \\
(35)\end{array}$ & $\begin{array}{c}100 \% \\
(774)\end{array}$ \\
\hline $\begin{array}{l}\text { Overall, political theory is UNDER-represented in the areas } \\
\text { mentioned above. }\end{array}$ & $\begin{array}{c}17.3 \% \\
(132)\end{array}$ & $\begin{array}{c}36.8 \% \\
(281)\end{array}$ & $\begin{array}{c}29.3 \% \\
(224)\end{array}$ & $\begin{array}{c}14.4 \% \\
(110)\end{array}$ & $\begin{array}{l}2.2 \% \\
(17)\end{array}$ & $\begin{array}{r}100 \% \\
(764)\end{array}$ \\
\hline $\begin{array}{l}\text { Overall, political theory is OVER-represented in the areas } \\
\text { mentioned above. }\end{array}$ & $\begin{array}{l}1.2 \% \\
(9)\end{array}$ & $\begin{array}{l}2.1 \% \\
(16)\end{array}$ & $\begin{array}{c}24.0 \% \\
(181)\end{array}$ & $\begin{array}{l}44.6 \% \\
(336)\end{array}$ & $\begin{array}{c}28.1 \% \\
(212)\end{array}$ & $\begin{array}{l}100 \% \\
(754)\end{array}$ \\
\hline Political theory is respected in my department. & $\begin{array}{l}31.2 \% \\
(244)\end{array}$ & $\begin{array}{c}44.2 \% \\
(346)\end{array}$ & $\begin{array}{l}9.1 \% \\
(71)\end{array}$ & $\begin{array}{c}11.5 \% \\
(90)\end{array}$ & $\begin{array}{l}4.0 \% \\
(31)\end{array}$ & $\begin{array}{r}100 \% \\
(782) \\
\end{array}$ \\
\hline Political theory is respected by political scientists generally. & $\begin{array}{l}3.2 \% \\
(25)\end{array}$ & $\begin{array}{c}20.7 \% \\
(161)\end{array}$ & $\begin{array}{l}29.5 \% \\
(230)\end{array}$ & $\begin{array}{l}39.4 \% \\
(307)\end{array}$ & $\begin{array}{l}7.2 \% \\
(56)\end{array}$ & $\begin{array}{r}100 \% \\
(779)\end{array}$ \\
\hline
\end{tabular}

\section{THE PLACE OF THEORY IN POLITICAL SCIENCE}

As mentioned above, one main motivation for conducting this survey was the perennial debate over whether theory belongs in political science. Perhaps not surprisingly, of the 781 respondents to a question about whether political science is the right academic "home" for political theory, 92.7\% (724) said "yes." A related series of questions asked about respondents' views regarding the current status of political theory within the discipline. The results, summarized in Table 1 , show both that

Table 2

\section{Amount of Publication Required for Tenure in Respondents' Departments}

\begin{tabular}{lrr} 
& \% & N \\
\hline Multiple books & 2.2 & 16 \\
\hline At least one book (and some articles) & 37.2 & 274 \\
\hline Several articles (more than 5) & 17.9 & 132 \\
\hline Some articles (2-5) & 25.8 & 190 \\
\hline At least one peer-reviewed article & 2.9 & 21 \\
\hline Any publications at all & 8.7 & 64 \\
\hline $\begin{array}{l}\text { Publications are not required for tenure in } \\
\text { my department }\end{array}$ & 5.3 & 39
\end{tabular}

Column Totals

100 political theorists are concerned about their place within political science, and that, in many cases, they are unsure about theory's current status.

Another question asked about the numbers and proportions of theorists in the respondents' departments. The mean

Table 3

Length of Time Respondents Spent on Tenure-Track Job Market after Receiving Ph.D.

\begin{tabular}{lccc} 
& \% & CUM. \% & N \\
\hline $\begin{array}{l}\text { Less than 1 year (includes finding a } \\
\text { job before completing the Ph.D.) }\end{array}$ & 46.0 & 46.0 & 347 \\
\hline 1 year & 9.5 & 55.6 & 72 \\
\hline 2 years & 11.1 & 66.7 & 84 \\
\hline 3 years & 7.8 & 74.5 & 59 \\
\hline 4 years & 5.3 & 79.8 & 40 \\
\hline 5 or more years & 9.3 & 89.1 & 70 \\
\hline $\begin{array}{l}\text { I have never held a tenure-track } \\
\text { appointment }\end{array}$ & 7.8 & 96.9 & 59 \\
\hline $\begin{array}{l}\text { I did not look for a tenure-track } \\
\text { position right away }\end{array}$ & 3.1 & 100 & 23 \\
\hline
\end{tabular}

100 
Table 4

\section{Rank Ordering of Scholars Who Have Had the Greatest Impact on Political Theory in the Past 20 Years}

\begin{tabular}{|c|c|c|c|c|c|}
\hline VOTES & NAME & VOTES & NAME & VOTES & NAME \\
\hline 279 & Rawls, John & 15 & Brown, Wendy & 6 & Shapiro, Ian \\
\hline 148 & Habermas, Jürgen & 14 & Agamben, Giorgio & 6 & Waldron, Jeremy \\
\hline 122 & Foucault, Michel & 14 & Pocock, J.G.A. & 6 & West, Cornel \\
\hline 84 & Connolly, William & 14 & Voegelin, Eric & 5 & Baudrillard, Jean \\
\hline 73 & Strauss, Leo & 13 & Berlin, Isaiah & 5 & Huntington, Samuel \\
\hline 71 & Walzer, Michael & 12 & Benhabib, Seyla & 5 & Jaffa, Harry V. \\
\hline 70 & Taylor, Charles & 12 & Oakeshott, Michael & 5 & Laclau, Ernesto \\
\hline 64 & Wolin, Sheldon & 11 & Dworkin, (Ronald? Andrea?) & 5 & McWilliams, Wilson Carey \\
\hline 62 & Butler, Judith & 11 & Elshtain, Jean & 5 & Meier, Heinrich \\
\hline 53 & Arendt, Hannah & 11 & Shklar, Judith & 5 & Putnam, Robert \\
\hline 45 & Skinner, Quentin & 10 & Deleuze, Gilles & 5 & Rancière, Jacques \\
\hline 44 & Rorty, Richard & 10 & Sen, Amartya & 5 & Riker, William \\
\hline 37 & Sandel, Michael & 10 & Wolin, (Sheldon? Richard?) & 5 & Rogin, Michael \\
\hline 37 & Young, Iris Marion & 9 & Euben, J. Peter & 5 & Spivak, Gayatri \\
\hline 35 & Mansfield, Harvey & 9 & Fraser, Nancy & 5 & Žižek, Slavoj \\
\hline 35 & Nussbaum, Martha & 9 & Gutmann, Amy & 4 & Cohen, G.A. \\
\hline 27 & Maclntyre, Alasdair & 9 & Pettit, Philip & 4 & Elster, Jon \\
\hline 26 & Derrida, Jacques & 9 & Skinner, (B.F.? Quentin?) & 4 & Gadamer, Hans-Georg \\
\hline 25 & Nozick, Robert & 8 & Galston, William & 4 & Gunnell, John \\
\hline 25 & Pateman, Carole & 8 & Kateb, George & 4 & Hardt (Michael) and Negri (Antonio) \\
\hline 24 & Dahl, Robert & 8 & Schmitt, Carl & 4 & Lowi, Theodore \\
\hline 21 & Bloom, Allan & 7 & MacKinnon, Catharine & 4 & McWilliams, (Wilson?) Carey \\
\hline 21 & Kymlicka, Will & 7 & Pitkin, Hanna & 4 & Nietzsche, Friedrich \\
\hline 21 & Okin, Susan Moller & 7 & Said, Edward & 4 & Rosenblum, Nancy \\
\hline 19 & Dworkin, Ronald & 6 & Bruell, Christopher & 4 & Smith, Rogers \\
\hline 17 & Barber, Benjamin & 6 & Manent, Pierre & 4 & Zuckert, Michael \\
\hline 17 & Pangle, Thomas & 6 & Raz, Joseph & & \\
\hline
\end{tabular}

Note: This list includes only those scholars who received at least four votes.

percentage of tenured or tenure-track faculty teaching political theory in respondents' departments is $16.9 \%$, while the median is $20 \%$. However, a follow-up survey revealed that the median at Ph.D.-granting institutions is lower (see below for details).

A final question in this set asked how many theory classes the respondent's department offers in the average year (counting different sections of the same course separately). The mean answer was 6.5 , the median was 5 , and the mode was $4(N=744)$.

\section{WHAT IT'S LIKE TO BE A POLITICAL THEORIST}

A second motivation for undertaking the survey was to investigate the professional experiences of political theorists. One question in this series asked how many courses the respondent is required to teach per academic year. The mean answer was 5.5 , the median answer was 5 , and the modal answer was
4. However, $24.4 \%$ (182) of respondents said that they teach 6 classes per year, and $17.7 \%(132 ; N=747)$ said they teach 8 . A related question asked how much of that teaching is in theory. Just over half of those answering this question $(53.2 \%$, or 412 respondents) reported that theory makes up only half or less of their teaching load, while only just over a third $(35.4 \%$, or 274 respondents; $N=774$ ) reported that theory makes up at least three-quarters of their teaching.

Of respondents who answered a question about whether their school offers tenure, $96.9 \%(747 ; N=771)$ answered affirmatively. Those whose departments do offer tenure saw a follow-up question about the relative importance of teaching, research, and service in tenure decisions at their schools. Of respondents answering these questions, $54.1 \%(397 ; N=731)$ identified teaching, $45.5 \%(334 ; N=729)$ identified research, and only $0.4 \%(3 ; N=732)$ identified service as being the most 
Table 5

Rank Ordering of Scholars Doing Excellent Work Today Whose Work Will Be Influential during the Next 20 Years

\begin{tabular}{|c|c|c|c|c|c|}
\hline VOTES & NAME & VOTES & NAME & VOTES & NAME \\
\hline 40 & Markell, Patchen & 8 & Gillespie, Michael & 5 & Rawls, John \\
\hline 39 & Brown, Wendy & 8 & Manent, Pierre & 5 & Ryn, Claes \\
\hline 37 & Connolly, William & 8 & Pogge, Thomas & 5 & Skinner, Quentin \\
\hline 29 & Honig, Bonnie & 8 & Rancière, Jacques & 5 & Thiele, Leslie Paul \\
\hline 19 & Mansfield, Harvey & 7 & Allen, Danielle & 5 & Waldron, Jeremy \\
\hline 19 & Nussbaum, Martha & 7 & Ceasar, James & 5 & White, Stephen \\
\hline 18 & Kymlicka, Will & 7 & George, Robert & 5 & Žižek, Slavoj \\
\hline 18 & Taylor, Charles & 7 & Hirschmann, Nancy & 4 & Appiah, Kwame Anthony \\
\hline 17 & Pettit, Philip & 7 & Lawler, Peter & 4 & Arnhart, Larry \\
\hline 16 & Benhabib, Seyla & 7 & Zuckert, Catherine & 4 & Eckersley, Robyn \\
\hline 16 & Butler, Judith & 6 & Dean, Jodi & 4 & Ellis, Elisabeth \\
\hline 15 & Deneen, Patrick & 6 & Deitz, Mary & 4 & Flathman, Richard \\
\hline 15 & Pangle, Thomas & 6 & Mansbridge, Jane & 4 & Goodin, Robert \\
\hline 15 & Walzer, Michael & 6 & Muthu, Sankar & 4 & Haraway, Donna \\
\hline 14 & Euben, Roxanne & 6 & Nichols, Mary & 4 & Held, David \\
\hline 14 & Zuckert, Michael & 6 & Smith, Rogers & 4 & Kohn, Margaret (Peggy) \\
\hline 13 & Shapiro, lan & 6 & Tully, James & 4 & Krause, Sharon \\
\hline 12 & Dryzek, John & 5 & Agamben, Giorgio & 4 & Maclntyre, Alasdair \\
\hline 11 & Gutmann, Amy & 5 & Ball, Terence & 4 & Mehta, Uday \\
\hline 11 & Habermas, Jürgen & 5 & Bartlett, Robert & 4 & Meier, Heinrich \\
\hline 10 & Bennett, Jane & 5 & Cohen, Joshua & 4 & Mills, Charles \\
\hline 10 & Sandel, Michael & 5 & Collins, Susan & 4 & Mitchell, Joshua \\
\hline 10 & Villa, Dana & 5 & Dienstag, Joshua Foa & 4 & Nelson, Eric \\
\hline 10 & Zerilli, Linda & 5 & Dumm, Thomas & 4 & Okin, Susan Moller \\
\hline 9 & Barber, Benjamin & 5 & Farr, James & 4 & Orwin, Clifford \\
\hline 9 & Elshtain, Jean & 5 & Frank, Jill & 4 & Rehfeld, Andrew \\
\hline 9 & Pitts, Jennifer & 5 & Galston, William & 4 & Sandoz, G. Ellis \\
\hline 9 & Sen, Amartya & 5 & Macedo, Stephen & 4 & Saxonhouse, Arlene \\
\hline 9 & Tuck, Richard & 5 & Mahoney, Daniel & 4 & Schall, James \\
\hline 8 & Bruell, Christopher & 5 & McCormick, John & 4 & Smith, Steven \\
\hline 8 & Coles, Romand & 5 & Nederman, Cary & 4 & Strong, Tracy \\
\hline 8 & Fraser, Nancy & 5 & Rahe, Paul & 4 & Yack, Bernard \\
\hline
\end{tabular}

Note: This list includes only those scholars who received at least four votes.

Table 3. Two noteworthy findings are that $55.6 \%$ (419) of respondents who answered this question found a tenure-track job within a year of receiving their Ph.D., and that nearly $90 \%$ (672; $N=754)$ of those looking for one found a tenure-track position within five years.

A vast majority 90.6\% (696; $N=768$ ) of respondents reported that they were political scientists by training, but of those only $66.3 \%(451 ; N=680)$ indicated that political theory was their primary subfield, while 19.7\% (113; $N=574)$ indicated that it was their secondary field. That suggests that more than $20 \%$ of respondents who are teaching political theory are not specialists in the field (adding together those who are not political scientists with those for whom theory is neither their primary nor secondary field).

Of those who reported being political scientists by training $81.5 \%(555 ; N=681)$ belong to the APSA. Of these, only $44.9 \%$ (249; $N=554$ ) belong to the Foundations of Political Thought organized section within the APSA. This suggests that a majority of the people teaching political theory in the U.S. today are members of the APSA, but not of the Foundations section.

\section{RANKINGS}

Several questions asked respondents to rank scholars, presses, journals, and professional associations. The results are presented in Tables 4-8. All of the ranking questions had the same basic format, asking respondents to identify up to five

important factor in tenure decisions at their institution. ${ }^{6}$ Those who indicated that their school grants tenure were also asked how many and what type of publications, if any, were required for tenure. The results, summarized in Table 2, show that the majority of the respondents-6o.6\% $(446 ; N=736)$-are in departments that do not require a scholar to publish a book to gain tenure.

A final question in this set asked how much time the respondent had spent on the job market before finding a tenure-track position. The responses are summarized in entries for each category. The rank orderings were determined by the total number of votes received for each response.

\section{GRADUATE TRAINING IN POLITICAL THEORY}

The survey asked three questions about the training of graduate students. Respondents who indicated that their departments grant the M.A. or Ph.D. were asked whether their department offers theory as a primary or major area of concentration for graduate students; $68.2 \%(206 ; N=302)$ said "yes." Of those same respondents, only $33.9 \%(102 ; N=301)$ reported 
Table 6

\section{Rank Ordering of Journals Related to Political Theory That Respondents Report Reading}

\begin{tabular}{|c|c|c|c|c|c|}
\hline VOTES & JOURNAL & VOTES & JOURNAL & VOTES & JOURNAL \\
\hline 407 & Political Theory & 22 & Perspectives on Politics & 7 & Politics \& Gender \\
\hline 205 & American Political Science Review & 21 & $\begin{array}{l}\text { Signs: Journal of Women in Culture } \\
\text { and Society }\end{array}$ & 7 & Public Culture \\
\hline 121 & Review of Politics & 20 & Journal of the History of Ideas & 7 & Review of Metaphysics \\
\hline 90 & History of Political Thought & 16 & Perspectives on Political Science & 7 & Social Theory and Practice \\
\hline 74 & Polity & 15 & New Political Science & 6 & Humanitas \\
\hline 73 & Journal of Political Philosophy & 13 & $\begin{array}{l}\text { Hypatia: A Journal of Feminist } \\
\text { Philosophy }\end{array}$ & 6 & Politics \& Religion \\
\hline 67 & theory \& event & 12 & Political Studies & 5 & Journal of Social Philosophy \\
\hline 63 & Ethics & 11 & Critical Inquiry & 5 & Radical Philosophy \\
\hline 57 & Philosophy \& Public Affairs & 11 & Philosophy \& Social Criticism & 4 & $\begin{array}{l}\text { differences: a journal of feminist } \\
\text { cultural studies }\end{array}$ \\
\hline 54 & Journal of Politics & 11 & Political Science Reviewer & 4 & Ethics \& International Affairs \\
\hline 47 & Contemporary Political Theory & 9 & Telos & 4 & Gender and Politics \\
\hline 43 & Constellations & 7 & Modern Age & 4 & $\begin{array}{l}\text { Millennium: Journal of Internationa } \\
\text { Studies }\end{array}$ \\
\hline 41 & $\begin{array}{l}\text { Interpretation: A Journal of Political } \\
\text { Philosophy }\end{array}$ & 7 & New Left Review & 4 & Politics, Philosophy \& Economics \\
\hline 29 & European Journal of Political Theory & 7 & Polis & 4 & PS: Political Science \& Politics \\
\hline 23 & American Journal of Political Science & 7 & Political Science Quarterly & 4 & Rethinking Marxism \\
\hline
\end{tabular}

Note: This list includes only those journals that received at least four votes.

Table 7

\section{Rank Ordering of Publishers Related to Political Theory Whose Books Respondents} Report Reading

\begin{tabular}{ll|cl|cl} 
VOTES & \multicolumn{1}{c|}{ PUBLISHER } & VOTES & \multicolumn{1}{c|}{ PUBLISHER } & VOTES & \multicolumn{1}{c}{ PUBLISHER } \\
\hline 278 & Cambridge University Press & 22 & Hackett Publishing Company & 7 & I.S.I. Books \\
\hline 251 & Princeton University Press & 22 & Verso Books & 7 & New York University Press \\
\hline 235 & Oxford University Press & 18 & Blackwell (Wiley) & 7 & W.W. Norton \& Company \\
\hline 187 & University of Chicago Press & 18 & University of California Press & 5 & Continuum \\
\hline 138 & Harvard University Press & 17 & University of Missouri Press & 5 & Penguin \\
\hline 92 & Routledge & 16 & Columbia University Press & 5 & Temple University Press \\
\hline 76 & Rowman \& Littlefield & 16 & Johns Hopkins University Press & 5 & Transaction Publishers \\
\hline 60 & Duke University Press & 15 & Lexington Books & 5 & University Press of Kentucky \\
\hline 60 & Yale University Press & 15 & Stanford University Press & 4 & Basic Books \\
\hline 59 & University of Minnesota Press & 13 & Liberty Fund & 4 & Catholic University of America Press \\
\hline 48 & Cornell University Press & 11 & Pearson & 4 & Cengage Learning \\
\hline 47 & University Press of Kansas & 11 & University of Notre Dame Press & 4 & CQ Press \\
\hline 44 & Pennsylvania State University Press & 9 & Macmillan & 4 & St. Augustine's Press \\
\hline 28 & State University of New York Press & 9 & Sage & 4 & University of North Carolina Press \\
\hline 23 & MIT Press & 8 & Polity & & \\
\hline
\end{tabular}

Note: This list includes only those publishers that received at least four votes. Votes for subsidiaries were added to the vote totals for the named publishers. 
Table 8

\section{Rank Ordering of Professional Organizations Related to Political Theory to Which Respondents Report Belonging}

\begin{tabular}{|c|c|}
\hline VOTES & ORGANIZATION \\
\hline 496 & American Political Science Association (includes organized sections) \\
\hline 123 & Association for Political Theory \\
\hline 95 & Western Political Science Association (includes organized sections) \\
\hline 61 & Midwest Political Science Association \\
\hline 36 & International Conference for the Study of Political Thought \\
\hline 33 & American Society for Political and Legal Philosophy \\
\hline 27 & International Studies Association \\
\hline 24 & Southern Political Science Association \\
\hline 16 & Northeastern Political Science Association \\
\hline 14 & New England Political Science Association \\
\hline 14 & Society for Ancient Greek Philosophy \\
\hline 10 & International Political Science Association \\
\hline 9 & Law and Society Association \\
\hline 8 & American Philosophical Association \\
\hline 7 & Association for the Study of Law, Culture and the Humanities \\
\hline 7 & Society for Phenomenology and Existential Philosophy \\
\hline 6 & Canadian Political Science Association \\
\hline 6 & Eric Voegelin Society \\
\hline 6 & Southwest Political Science Association \\
\hline 5 & American Psychological Association \\
\hline 5 & American Society for Eighteenth-Century Studies \\
\hline 5 & Oakeshott Association \\
\hline 5 & Rousseau Association \\
\hline 4 & American Historical Association \\
\hline 4 & American Society for Public Administration \\
\hline 4 & $\begin{array}{l}\text { AMINTAPHIL (International Association for Philosophy of Law and Social } \\
\text { Philosophy) }\end{array}$ \\
\hline 4 & Christians in Political Science \\
\hline 4 & Hegel Society of America \\
\hline
\end{tabular}

Note: This list includes only those associations that received at least four votes.

that their department requires graduate students to take at least one political theory class. Further, all respondents were asked to rank political science Ph.D. programs in terms of the quality of their training in political theory; their responses are summarized in Table 9.

Because the original survey focused on individuals as the unit of analysis, rather than institutions, it was difficult to tell how representative the findings summarized above were of political science Ph.D. programs. To get a more complete picture of the status of political theory in American graduate programs, I conducted a follow-up survey of the graduate directors of the 129 programs identified by the APSA as granting a Ph.D. in political science. I received answers from 95 of the program directors, and was able to identify 10 other programs that are either currently inactive or offer a Ph.D. only in a coordinate field, such as public administration. For the remaining programs, I visited their websites and gathered as much information as possible. ${ }^{7}$ This follow-up survey found that theory is available as a major/primary field in $69.7 \%(83)$ and available as a secondary or minor field in $77.3 \%$ (92) of the active programs $(N=119)$. Only $27.7 \%$ (33) of active programs require their Ph.D. students to take at least one theory class. In terms of the percentage of Ph.D.s granted in theory in an average year, the mean response was $12.4 \%$ and the median was $10 \%(N=91)$. The mean percentage of theorists on the full-time, tenure-track faculty of the active Ph.D. programs is $16.9 \%$ and the median is $11.7 \%$ $(N=90)$. Regarding full-time, non-tenure track faculty, the mean percentage of theorists was $14 \%$, while the median was $0 \%(N=90)$.

\section{CONCLUSION}

My hope is that the results of these surveys will be the catalyst for a discussion among political theorists and within the discipline more broadly about the role of theory in political science, as well as about whether we are training graduate students appropriately for the jobs that await them. Knowing the actual state of political theory in the discipline is the first step in deciding whether we are happy with the status quo and, if not, how we might go about changing it.

\section{NOTES}

An earlier version of this essay was presented at the 2009 Annual Meeting of the American Political Science Association. I would like to thank my fellow panelists, and the members of the audience, for their helpful suggestions on that occasion. That earlier version of the paper has more complete versions of some of the tables included here, and is available through the Social Science Research Network at http://ssrn.com/abstract $=1463648$. I would also like to thank Prof. Jeff Sklar of the Statistics Department of California Polytechnic State University, San Luis Obispo, for his generous assistance as part of the University's Statistical Consulting Service.

1. My research has turned up only one other national survey of political theorists; Hajjar and Brzezinski's (1978) 1977 survey resulted in 172 responses.

2. Other findings from the survey, primarily concerned with what and how political theorists teach, will be published separately.

3. The debate has been going on for at least 50 years now. For example, see Smith (1957), which contains an excellent short list of earlier related articles. See also Cobban (1953).

4. The following students (and a few former students!) provided invaluable help (much of it as volunteers), and have my profound thanks: Mallory Homewood, Kayvan Chinichian, Alex Finch, Alyson Pietrowski, Jimmy Sotelo, Leah Coleman, Alex Cunny, Christine Stradford, Manuel Reynoso, Maggie Stone, Janelle Little, Rob Binning, Andy Hillier, Doug Johns, Taylor Roschen, Sarah Prince, Lauren Schneider, Danielle Kennedy.

5. These are the scholars we initially identified as theorists, minus those whose invitations were returned as undeliverable or who identified themselves as ineligible, plus the people in the couldn't-rule-them-out category who responded and identified themselves as theorists. 


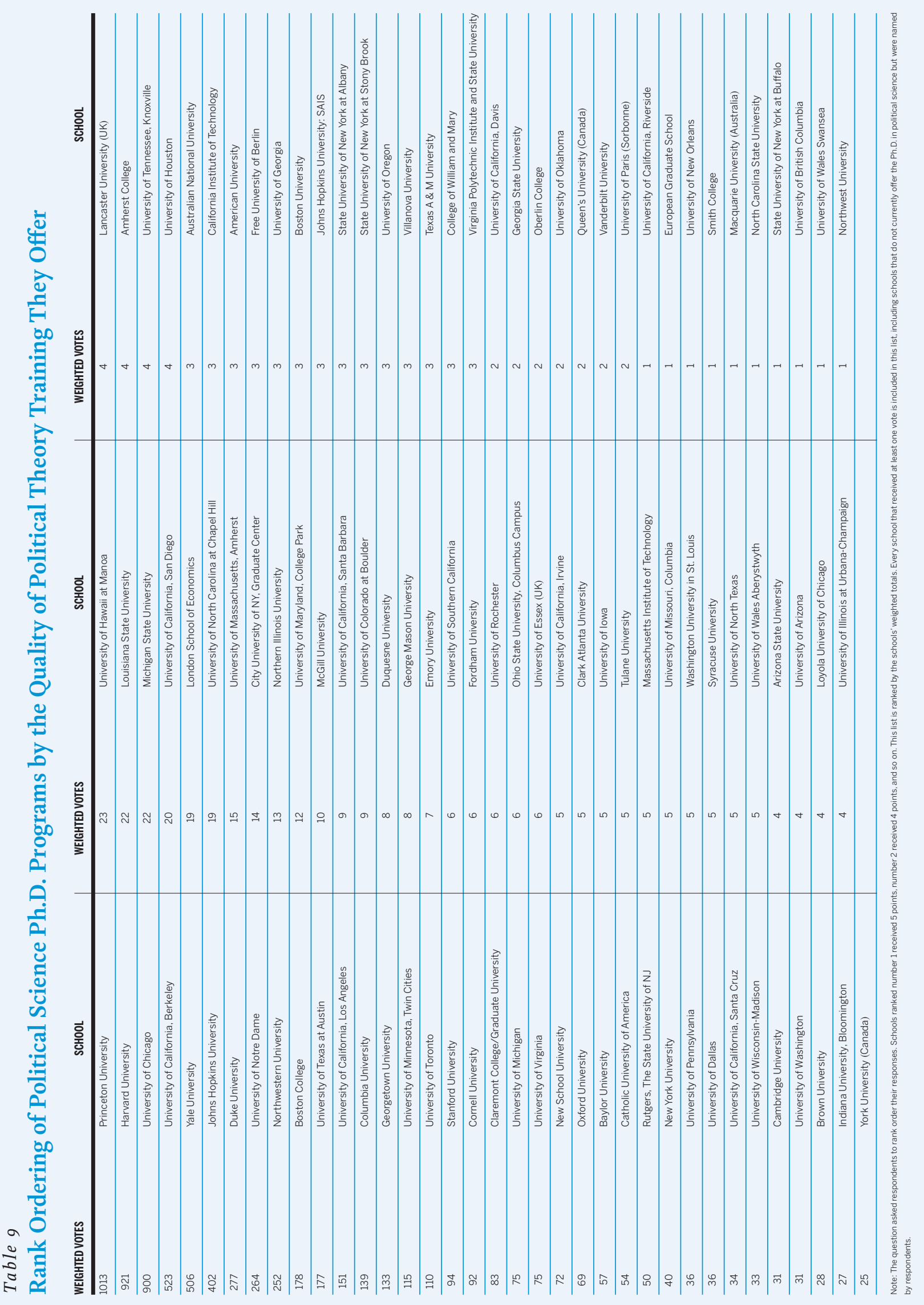


6. Rothgeb and Burger's (2009) recent survey of department chairs has revealed a great deal of information about tenure in political science generally.

7. A table showing the complete results is available in the version of this paper presented at the 2009 Annual Meeting of the American Political Science Association. That paper is available through the Social Science Research Network: http://ssrn.com/abstract $=1463648$.

\section{REFERE N CES}

APSA. 2001. APSA Survey of Political Science Departments, 20oo-2001. Washington, D.C.: American Political Science Association.
2007. Directory of Political Science Faculty \& Programs 2007-2008. Washington, D.C.: American Political Science Association.

Cobban, Alfred. 1953. "The Decline of Political Theory." Political Science Quarterly 68 (3): 321-37.

Hajjar, Sami G., and Steven Brzezinski. 1978. “Teaching Normative Political Theory: A Nationwide Faculty Survey." Teaching Political Science 5 (3): 295-306.

Rothgeb, John M., Jr., and Betsy Burger. 2009. "Tenure Standards in Political Science Departments: Results from a Survey of Department Chairs." PS: Political Science and Politics 42 (3): 513-19.

Smith, David G. 1957. "Political Theory and Political Science." American Political Science Review 51 (3): 734-46. 